Historia Slavorum Occidentis

2021, nr 4 (31)

ISSN 2084-1213

DOI: $10.15804 /$ hso210405

Karolina Kaczmarek (Poznań)

ORCID: 0000-0002-4736-4990

\title{
Autonomie terytorialne i kulturowe w Siedmiogrodzie. Dążenia i interpretacje
}

Keywords: Transylvania, Hungary, Romania, national minorities, autonomy

Słowa kluczowe: Siedmiogród, Węgry, Rumunia, mniejszości narodowe, autonomia

Abstract: The article presents the endeavours on the part of the multi-national and multicultural population living in Transylvania to create, within a span of several centuries, various types of autonomies, be it cultural or territorial.

\section{Wstęp}

Węgierska nazwa Siedmiogrodu to Erdély, czyli „kraina za lasem”. Od tego wyrazu pochodzi też nazwa rumuńska Ardeal. Natomiast polska nazwa Siedmiogród wiąże się z nazwą niemiecką Siebenbürgen, nadaną temu obszarowi przez osiedlających się tam Sasów i oznaczającą siedem wzgórz. W języku polskim równolegle stosowana jest też pochodząca z języka łacińskiego nazwa Transylwania, a w języku rumuńskim - Transilvania. W węgierskiej kronice średniowiecznej Anonima Gesta Hungarorum pojawiają się zarówno nazwy ad Erdeuelu, jak i de Terra Ultrasilvana, czy też Ultra Silvas. Nazwy łacińskie są jednak tłumaczeniem nazwy węgierskiej ${ }^{1}$.

1 L. Benkö, I. Bóna, Zs. Jakó, S. Tonk, K. Vekov, Erdély a keresztény magyar királyságban. Erdélyi Tudományos Füzetek 231, Kolozsvár 2011, s. 33-35. 
Siedmiogród to miejsce o bogatej tradycji wspólistnienia wielu kultur, narodowości i języków. W okresie starożytnym obejmował on Królestwo Dacji, był prowincją rzymską, przez kilka wieków stanowił integralną część Królestwa Węgier, potem był mniej lub bardziej uzależniony od imperium osmańskiego. Następnie miał status księstwa zależnego od Habsburgów, aż do całkowitego zjednoczenia z Austro-Węgrami. W 1918 r. Siedmiogród stał się przejściowo obszarem „autonomicznym”, zajętym przez wojska rumuńskie. Po zawarciu Traktatu w Trianon w 1920 r. Siedmiogród stał się ważną prowincją Rumunii, z wyjątkiem czterech lat w czasie drugiej wojny światowej, kiedy część jego ziem tymczasowo wróciła do Węgier.

\section{Autonomie kulturowe w Siedmiogrodzie}

Idea pewnego rodzaju autonomiczności narodów Siedmiogrodu sięga początków Królestwa Węgier. Na obszarze tym, podobnie jak w innych częściach królestwa Węgier, przez setki lat uprzywilejowane przez władców grupy ludności rządziły się własnymi prawami, przy założeniu, że nie były one sprzeczne z zarządzeniami króla Węgier lub księcia Siedmiogrodu. Miały one prawo do uchwalania statutów i do własnego sądownictwa. W 1437 r. została powołana Unia Trzech Narodów Siedmiogrodu: Węgrów, Seklerów i Sasów. Te trzy grupy, już wcześniej uprzywilejowane przez władców, uchwaliły, że są sobie równe i utworzyły wspólny lokalny parlament. Rozporządzenia tego organu nabierały mocy dopiero wtedy, gdy otrzymały pieczęć każdej z trzech społeczności. Unia stanowiła wspaniały przykład pokojowego współistnienia różnych narodowości w ramach jednego księstwa. Jej poważnym mankamentem było natomiast wykluczenie z procesu współrządzenia ludności wołoskiej. Kiedy Siedmiogród znalazł się pod kontrolą Habsburgów, cesarz zatwierdził prawa i przywileje trzech narodów aktem prawnym z 1691 r., tzw. Diploma Leopoldinum. Znalazł się w nim zapis, że we wszelkiego typu urzędach, czy to w administracji, czy sądownictwie, czy w instytucjach gospodarczych, zatrudniana będzie ludność urodzona w Siedmiogrodzie, to znaczy Węgrzy, Seklerzy i Sasi².

Węgrzy siedmiogrodzcy stanowili grupę stosunkowo spójną z Węgrami z innych obszarów królestwa. Mieli zasadniczo ten sam system praw i organizację administra-

2 M.A. Szabó, Betekintés az erdélyi szászok autonómiájába, [w:] Történelmi autonómiák a Kárpát-medencében. Székelyudvarhely, G.H. Hermann, Zs. Kolumbán, Csíkszereda 2004, s. 24-45, tu: s. 31 . 
cyjną, które funkcjonowały w całym królestwie. Natomiast dość specyficzne były dwie pozostałe grupy ujęte w Unii Trzech Narodów, tj. Seklerzy i Sasi.

Istnieje kilka teorii na temat pochodzenia Seklerów. Zgodnie z jedną z nich była to odrębna grupa wojskowych oddziałów pomocniczych, towarzysząca Węgrom zajmującym Kotlinę Karpacką. W taki sposób opisywały Seklerów najstarsze kroniki węgierskie ${ }^{3}$. Od XIII w. opisywano Seklerów jako plemię wywodzące się od Hunów, którzy przybyli do Siedmiogrodu po śmierci Attyli. W badaniach językoznawczych wyłaniają się dwa główne nurty. Według jednego z nich Seklerzy są z pochodzenia Węgrami, zawsze mówili w języku węgierskim, a ich odrębność wykształciła się w średniowieczu ze względu na rolę wojskową, jaką odgrywali. Według drugiego, Seklerzy to odłam ludu turkijskiego, być może było to plemię Kabarów. Lud ten wywodził się od Chazarów, ale w IX w. zbuntował się przeciwko nim i jeszcze przed zajęciem Kotliny Karpackiej przyłączył się do plemion węgierskich. Plemię to około $950 \mathrm{r}$. było dwujęzyczne, turkijsko-ugrofińskie. Wskazywać by na to mogło pismo stosowane przez Seklerów w średniowieczu (węg. rovásírás), gdzie spomiędzy 37 liter 21 jest staroturkijskich, trzy starogreckie i trzy z głagolicy. Są też cztery znaki, które fonetycznie nie pochodzą z języków turkijskich, tylko z ugrofińskich ${ }^{4}$. Grupa Seklerów zachowała autonomię organizacyjną, prawo do własnego sądownictwa i organizacji kościoła, nie wykształcił się system feudalny - członkowie tej społeczności byli wolnymi ludźmi. Każdy miał prawo do części wspólnej ziemi i miał obowiązek służby wojskowej. Seklerzy zachowali też przejęty od Węgrów pasterski tryb życia, a hodowla zwierząt pozostała ich głównym zajęciem również po tym, jak zajęli się uprawą roli. W książce wydanej w 1860 r. węgierski historyk László Kővári przytacza opisy wychowanego w Siedmiogrodzie biskupa Antala Verántza sporządzone niedługo po klęsce zadanej Węgrom przez Turków pod Mohaczem w 1526 r. Pisał on, że Siedmiogród zamieszkują trzy narodowości: Seklerzy, Węgrzy i Sasi. Szczególnie wiele uwagi biskup poświęcał Seklerom, o których pisał, że każdy $\mathrm{z}$ nich jest z pochodzenia szlachcicem, nawet jeżeli pracuje pługiem lub motyką. Dlatego Seklerzy nie płacą podatków, ale mają obowiązek stawić się do walki w wypadku wojny. Jeżeli wróg nadchodzi ze wschodu i północy, albo jeżeli wojna toczy się w granicach ojczyzny, to każdy z nich powinien się stawić i walczyć tak długo,

3 Chodzi tu przede wszystkim o Gesta Hungarorum napisane przez Anonima około $1200 \mathrm{r}$. Pierwotny egzemplarz nie zachował się, najstarszy zachowany egzemplarz pochodzi z XIII w.

4 Erdély rövid története, red. B. Köpeczi, Budapest 1989, s. 158.

5 Verántz - Antal Verancsics, biskup urodzony w 1504 r., sekretarz węgierskiego króla Jana Zápolyi. http://lexikon.katolikus.hu/V/Verancsics.html [dostęp: 25 II 2021]. 
aż wojna się nie skończy. Jeżeli wróg atakuje z Zachodu, to powinien stawić się co dziesiąty z nich, a żołnierze nie muszą pozostawać w obozie dłużej niż dwa tygodnie. Opisywane przez Verántza obowiązki Seklerów wobec kraju poza służbą wojskową nie wydają się wygórowane. Jak wyjaśniał, z okazji koronacji, ślubu i urodzin pierworodnego potomka każde gospodarstwo lub rodzina miała obowiązek dostarczyć jednego woła. Jeżeli królowi pierwsza urodziłaby się córka, to społeczność była zwolniona z obowiązku dostarczenia co trzeciego woła ${ }^{6}$. Natomiast Węgrzy - według Verántza - przybyli do Siedmiogrodu po Seklerach. Zachowali zasadniczo zwyczaje z królestwa, chociaż występowały pewne różnice. Dobrze uprawiali ziemię i byli bohaterscy w walce. Mieszkali raczej w wioskach, w ładnych, dużych dworkach i nosili piękne, kolorowe stroje $\mathrm{e}^{7}$.

Pierwsze grupy ludności z Zachodu, szczególnie niemieckiej z Nadrenii, a w mniejszym zakresie również walońskiej z Flandrii, przywędrowały do Siedmiogrodu w XII w., na zaproszenie króla węgierskiego Gézy II ${ }^{8}$. W Siedmiogrodzie grupy te zajęły obszar na południe od rzeki Maros i Olt, a żyjący tam wcześniej Seklerzy przenieśli się na teren, który do dzisiaj nazywany jest Seklerszczyzną (węg. Székelyföld, rum. Tinutul Secuiesc). Na ziemie te sprowadziło się wtedy ok. 500 rodzin, tj. 2-3 tys. osób. Reprezentowali oni różne warstwy społeczne, byli to chłopi, górnicy, szlachta oraz duchowieństwo. Przez kolejne stulecia do Siedmiogrodu napływała ludność z różnych obszarów kultury niemieckiej, szczególnie z okolic Magdeburga, Kolonii, Koblencji, Dolnej Saksonii, Westfalii i Luksemburga. Węgrzy określali te grupy wspólną nazwą „Niemcy”, a w późniejszym okresie, szczególnie w Siedmiogrodzie, „Sasi”. Społeczność ta otrzymała szeroką autonomię. W 1224 r. król Andrzej II zachęcił kolejne grupy ludności niemieckiej do osiedlenia się w Siedmiogrodzie, nadając im znaczne przywileje wyrażone w Złotej Bulli Wolności, tzw. Andreanum (węg. Arany szabadságlevél, niem. der Goldene Freibrief). Zgodnie z zapisami bulli osadnicy, którzy zajmowali ziemie królewskie, mieli status ludzi wolnych. Nie podlegali oni zwierzchnictwu magnatów, a kontakt z królem utrzymywali za pośrednictwem sędziów. Mieli prawo do tworzenia własnych statutów i odrębnego, niezależnego sądownictwa. Przywilej Andrzeja II nadawał im też prawo do użytkowania lasów i wody wspólnie z Wołochami i Pieczyngami. Przyczyny nadania tak szerokiej autonomii były dwojakie. Po pierwsze, ludność ta musiała, w przeciwieństwie do Wę-

6 L. Kőváry, Erdély történelme. 3. kötet (A Zápolyák kora), Pest, Kolozsvár 1860, s. 4.

7 Tamże, s. 5.

8 M.A. Szabó, Betekintés az erdélyi, s. 25. 
grów czy Wołochów, pokonać daleką drogę, stąd konieczne były specjalne zachęty. Po drugie, Andrzej II w Złotej Bulli z 1222 r. nadał przywileje szlachcie węgierskiej, więc bulla saska miała zrównoważyć wpływy węgierskich magnatów na tym obszarze. Z tego też względu kolejni królowie potwierdzali i rozszerzali prawa społeczności Sasów. Król Maciej Korwin w 1464 r. nadał im prawo wyboru własnego żupana, dzięki czemu mieli kontrolę nad administracją państwową. Ponadto, miasta będące stolicą prowincji zamieszkałych w dużej mierze przez Sasów, w przeciwieństwie do stolic prowincji zamieszkałych głównie przez Seklerów, nie rozwijały się w oparciu o prawo węgierskie, tylko o odrębne prawo ustalane przez samych Sasów. W 1583 r. Stefan Batory, jako król Polski i książę Siedmiogrodu, zatwierdził Księgę Prawa Statuta Jurium Municipalium Saxonum in Transylvania ${ }^{9}$ stworzoną dla całej społeczności Sasów siedmiogrodzkich. Obowiązywała ona przez 300 lat, aż do wprowadzenia przez Habsburgów w 1853 r. kodeksu austriackiego ${ }^{10}$. Wspomniany wcześniej biskup Verántz pisał o Sasach, że zachowali rysy saskie, ich zwyczaje i język. Był to lud pracowity, zajmujący się rzemiosłem, uprawą ziemi i handlem. Ludność zadowalała się prostym jedzeniem, przykładała większą wagę do domów i umeblowania niż pozostałe narodowości, miała najładniejsze wioski, a ich ziemia była najlepiej uprawiana. Sasi mieli winnice w całym Siedmiogrodzie, kradzieże znali tylko ze słyszenia, natomiast wojny woleli wspomagać bardziej pieniądzem niż siłą zbrojną ${ }^{11}$. Zarówno to, że przybyła z Zachodu ludność funkcjonowała w Siedmiogrodzie pod wspólną nazwą „Niemcy” czy też „Sasi”, jak i przywileje królewskie, a później kodeks, doprowadziły do scalenia i utrwalenia autonomicznej, specyficznej kultury, rozwijającej się w oderwaniu od kultury niemieckiej wykształconej w Europie Zachodniej.

O Wołochach zamieszkujących Półwysep Bałkański wspomina się od X w. W okresie rozkwitu Bizancjum cesarz Manuel najeżdżał tereny Siedmiogrodu, a niektórzy żołnierze byli Wołochami. Ludność ta prawdopodobnie już w XII w. zamieszkiwała w niewielkiej liczbie obszary południowych i wschodnich Karpat, natomiast ślady ich stałego pobytu pojawiają się pod koniec XIII w. Do XIV w. Wołosi zwykle prowadzili pasterski tryb życia lub pracowali na roli jako chłopi pańszczyźniani na obszarze Bałkanów. Grupy, które pozostały na południu Europy, w szczególności te zamieszkałe w miastach, dość szybko uległy asymilacji z ludnością bułgarską czy

9 Dostępny tekst drukowany: Matthias Fronius, Claudiopoli: typis, Coll: Reform:, anno 1779. https://mek.oszk.hu/19200/19267/ [dostęp: 20 II 2021].

10 M.A. Szabó, Betekintés az erdélyi, s. 24-30.

11 L. Kőváry, Erdély történelme, s. 4. 
grecką. Własną, autonomiczną tożsamość zbudowały natomiast społeczności, które przeniosły się na obszary Siedmiogrodu, Wołoszczyzny i Mołdawii. Wzmianki o mieszkających tam Wołochach (węg. olah) pojawiają się w drugiej połowie XIV w. Po najeździe tatarskim w latach 1241-1242 Siedmiogród opustoszał. Później pustkę tę wypełniała ludność wołoska, co zmieniło wcześniejszy obraz etniczny tych obszarów. Wołosi przez długi czas byli wędrownym ludem pasterskim. Mieszkali w rozrzuconych osadach w górach i lasach, często się przemieszczając. Część z nich tworzyła też oddziały wojskowe, które miały za zadanie ochronę granic Królestwa Węgier razem z Seklerami i Pieczyngami. Z czasem zaczęli organizować struktury składające się z osad, na czele których stali kniaziowie (węg. kenéz, łac. kenesius), oraz grupy osad kierowanych przez wojewodę. Ponieważ eksploatowali oni obszary, które nie były w żaden inny sposób wykorzystywane, co było korzystne dla gospodarki, królowie węgierscy wspierali taką działalność. W dokumencie z 1263 r., w którym król Béla IV ustalał prawa arcybiskupa Ostrzychomia, zawarto zapewnienie, że arcybiskup otrzyma dziesiątą część bydła i owiec, które król otrzyma od Wołochów i Seklerów (Item similiter de pecudibus et pecoribus exigendis ab Olachis et Siculis idem Archiepiscopus percipiet decimam partem ${ }^{12}$ ). Z dokumentu wynika, że Wołosi oddawali królowi jedno zwierzę na pięćdziesiąt ze stada, był to więc system podatkowy podobny do stosowanego na Półwyspie Bałkańskim. O Wołochach mieszkających przy południowej granicy Siedmiogrodu dowiadujemy się również z dokumentu wydanego w 1263 r. przez węgierskiego „króla młodszego” Stefana. W dokumencie król ofiarowuje jednemu z magnatów trzy wioski, z wyłączeniem ziem należących do kniaziów, najprawdopodobniej wołoskich, co świadczy o tym, że uznawał on prawa ziemskie kniaziów ${ }^{13}$. Duża grupa ludności wołoskiej przybyła do Siedmiogrodu w XIV w. Na przykład w 1334 r. wojewoda wołoski Bogdan przeniósł się z Mołdawii na Węgry wraz z tak wielką liczbą ludności, że przenosiny zajęły ponad dziewięć miesięcy. W 1359 r. sześciu członków znaczącej rodziny wołoskiej przyjechało z Wołoszczyzny do Banatu, gdzie otrzymali oni od króla węgierskiego 13 wsi, a sześć lat później - pięć kolejnych majątków. W 1365 r. wojewoda Balk wraz w czworgiem rodzeństwa przeprowadził się na Węgry z Wołoszczyzny, co stało się początkiem kolejnej fali napływu ludności wołoskiej do Siedmiogrodu, a jeden z braci przeniósł

12 Oryginał listu znajduje się w archiwum arcybiskupim w Ostrzychomiu. Pełna treść opublikowana, [w:] Gy. Fejér, Codex diplomaticus Hungariae ecclesiasticus ac civilis, t. IV, vol. III. 133-136. 1. Budae, https://library.hungaricana.hu/hu/view/KozMagyOkmanytarak_Codex_ Diplomaticus_Tom_4_vol_3/?pg=132\&layout=s [dostęp: 26 IV 2021].

13 B. Köpeczi, Erdély története három kötetben, Budapest 1986, s. 305. 
się potem do Polski. Królowie Karol Robert i Ludwik Wielki włączali wołoskich kniaziów i wojewodów w szeregi szlachty w ramach nagrody za zasługi wojenne. Najszybciej proces ten rozpoczął się na obszarze Murmaroszu, ponieważ te obszary były najbardziej zagrożone przez wroga. Początkowo Wołosi otrzymywali tytuły nobilis vaivoda i nobilis kenezius co oznaczało, że ich szlachectwo było ograniczone - nadal płacili królowi podatki i byli zobowiązani do służby wojskowej. Z czasem jednak nabywali oni prawa równe szlachcie węgierskiej. O ile jednak Sasi i Seklerzy, którzy byli włączani do stanu szlacheckiego otrzymywali majątki w komitatach poza ziemią zasiedloną przez ludność saską i seklerską, o tyle kniaziowie i wojewodowie otrzymywali jako majątki tereny, którymi wcześniej zarządzali. Mieszkająca na nich ludność była tym samym spychana do roli chłopów pańszczyźnianych, zależnych od „nowej szlachty”, co skutkowało znaczącym rozwarstwieniem społecznym Wołochów. Warto natomiast zaznaczyć, że wołoska szlachta z Marmaroszu (węg. Máramaros, rum. Maramureş) już około 1380 r. tworzyła własne samorządy na wzór samorządów węgierskich, z własnym sądownictwem. Również w prowincji Hátszeg (rum. Hațeg) w XIV w. siedzibę miał sąd kniaziowski. Po włączeniu kniaziów do szlachty węgierskiej sąd ten został scalony z sądem komitatu Hunyad (rum. Hunedoara) ${ }^{14}$. W liście wydanym w 1451 r. przez wojewodę wołoskiego Jánosa Hunyadiego, bohatera Węgier i ojca króla Węgier Macieja Korwina, znajduje się wyrażenie sedes valachicales, co świadczy o tym, że Wołosi tworzyli w Siedmiogrodzie samorządy. Vajk Hunyady, ojciec Jana Hunyadyego, był synem wołoskiego kniazia. Vajk otrzymał tytuł szlachecki i prawo do zasiedlania obszarów siedmiogrodzkich Wołochami, pod warunkiem że będą oni podporządkowani królowi węgierskiemu. W XV w., wraz ze wzrostem sławy Jana Hunyadyego, kolejne rodziny wołoskie dołączały do szlacheckiej elity Węgier ${ }^{15}$. Potwierdzają to zapiski Verántza o Wołochach. Stwierdzał on, że ilościowo dorównują oni pozostałym trzem narodowościom, jednak nie mają żadnych przywilejów z wyjątkiem ludności z prowincji Hátszeg, która zasłużyła się w walce $\mathrm{z}$ Turkami przy boku Hunyadiego i z tego powodu wielu z nich otrzymało tytuł szlachecki. Większość natomiast to chłopi pańszczyźniani u Węgrów, zamieszkują zwykle w górach i dolinach ze swoimi stadami ${ }^{16}$. Nazwa Wołoch nie zawsze dotyczyła jednej grupy etnicznej - często określano nią po prostu ludzi prowadzą-

14 Tamże, s. 305, 341-345.

15 L. Tamás, Az erdélyi oláhság, [w:] A történeti Erdély, red. M. Asztalos, Budapest 2001, s. 419-455, tu: s. 422-423.

16 L. Kőváry, Erdély történelme, s. 6. 
cych wędrowny, pasterski tryb życia. Nazwa Rumun (węg. Román) była wewnętrzną, etniczną nazwą grupy, określanej przez Węgrów słowem olah. Pierwotna forma słowa ma pochodzenie germańskie, natomiast Węgrzy zapożyczyli je od Słowian południowych. Pochodzi od formy vlachъ, która w procesie zmian fonetycznych przekształciła się w formę węgierską * ${ }^{*}$ olah > olah ${ }^{17}$. Później Węgrzy zapożyczyli od ludności wołoskiej nazwę Román, którą obecnie stosują na określenie współczesnej ludności rumuńskiej. W okresie walk wolnościowych 1848-1849 na wniosek narodowości rumuńskiej forma Román została włączona do węgierskiego języka urzędowego, a w języku powszechnym funkcjonowała jako synonim, w różnych postaciach: rumunt, rumán, rumony, a na początku XX w. najbardziej rozpowszechniona stała się forma rumén ${ }^{18}$. W słowniku języka węgierskiego słowo Román pojawiło się dopiero w 1862 r. ${ }^{19}$ Natomiast po drugiej wojnie światowej użycie w języku węgierskim nazwy olah (Wołoch) zaczęło mieć wymowę prześmiewczą, obraźliwą ${ }^{20}$.

Wczesne autonomie wołoskie nie utrzymały się w takim zakresie jak u Sasów czy Seklerów. Wyjątek stanowiła autonomia z prowincji Chioar (łac. Districtus Köváriensis, węg. Kővár, rum. Țara Chioarului lub Chioar), na obszarze Partium²1. Ludność wołoska z tego terenu otrzymała przywileje w zamian za służbę wojskową, na początku w szczególności związaną z potrzebami zamku Chioar. Obszar ten leżał na górzystym terenie porośniętym lasem i zamkniętym dwoma rzekami, co mogło być jedną z przyczyn tak długiego utrzymania odrębności. Ponieważ mało było tam ziemi uprawnej, więc ludność utrzymywała się w dużej mierze z wykorzystania owoców lasu, wypasu zwierząt oraz produkcji palinki z owoców śliwy, najczęściej dziko rosnącej. Swobody ograniczone były jednak przez system feudalny głęboko zakorzeniony na tym obszarze ${ }^{22}$. Autonomia ta została zniesiona ustawą z $1876 \mathrm{r}^{23}$

17 A. Rácz, Nyugati népek megnevezéseinek változásai a magyar nyelvben, Magyar Nyelvjárások 47 (2009), s. 81-97, tu: s. 83.

18 J.N. Fodor, Megjegyzések népnévi eredető tulajdonneveinkröl, Névtani Értesítő 34 (2012), s. 179-191, tu: s. 182.

19 G. Czuczor, J. Fogarasi, A magyar nyelv szótára. Pest, [később] Budapest 1862-1874.

20 A. Rácz, Nyugati népek, s. 82.

21 K. Kocsis. Területi autonómiák a Kárpát-medencében - 1920 előtt, A Miskolci Egyetem Közleményei, A sorozat, Bányászat, 82 kötet (2011), s. 23-33, tu: s. 28.

22 E. Bánkiné Molnár, Eltünt autonómiák. A Jászkun kerület és Kővár-vidék, [w]: Ingenia et studia. Tanulmányok a 80 esztendős Iványosi-Szabó Tibor tiszteletére, Kecskemét 2013, s. 43-52, tu: 43-44, 48.

23 1876. évi XXXIII. törvénycikk némely törvényhatóság területének szabályozásáról és az ez- 


\section{Propozycje autonomii w kontekście zjednoczenia Siedmiogro- du z Rumunią}

Słowo „autonomia” pochodzi od greckich słów av̉ đós (autos) - sam, moje, własne - i vó zana ze znaczeniem odczytywanym z jego etymologii, określając, że jest to „prawo do samodzielnego rozstrzygania spraw wewnętrznych danej zbiorowości, dotyczące narodu, miasta, instytucji itp.; samostanowienie" ${ }^{24}$. Współcześnie istnieje wiele definicji prawnych słowa autonomia, żadna z nich nie jest jednak powszechnie uznawana jako jedynie obowiązująca w prawie międzynarodowym. Termin jest niedookreślony i może być rozumiany bardzo różnie. Zgodnie z prawami lingwistyki samo słowo jest tylko znakiem, które zaczyna nieść znaczenie, gdy zostanie umieszczone w jakimś kontekście. Zasada ta znana jest również prawnikom. W wypadku wątpliwości co do znaczenia słów sędzia nie może po prostu zajrzeć do słownika, ale na podstawie kontekstu, wartości społecznych, podobnych przepisów prawa i innych istotnych okoliczności musi znaleźć rozsądne argumenty, które uzasadnią prawidłowość podjętej przez niego decyzji ${ }^{25}$. Powyższa zasada powinna być zastosowana również przy interpretacji znaczenia słowa „autonomia”. Bez dokładnego kontekstu użycia nie można go całkowicie dookreślić, chociażby ze względu na bardzo zróżnicowany status grup dążących do uzyskania autonomii w wielu krajach świata oraz różnorodność rozwiązań wynikających raczej z praktyki, zwyczajów i potrzeb lokalnych niż z teoretycznych definicji. ${ }^{26}$ Dlatego rozumienie tego terminu, szczególnie w kontekście politycznym, może się znacząco różnić.

Chociaż słowo „autonomia” zawsze będzie stosowane w sposób elastyczny, to do pewnego stopnia można jego znaczenie dookreślić przez dodanie przymiotnika,

zel kapcsolatos intézkedésekröl, https://net.jogtar.hu/getpdf?docid=87600033.TV\&targetdate $=\&$ printTitle $=1876 .+$ évi+XXXIII.+törvénycikk\&refrefe=1000ev [dostęp: 26 II 2021] .

24 Słownik języka polskiego, red. M. Szymczak, t. 1-3, Warszawa 1978-1981, s. 101.

25 K. Kaczmarek. Precyzja i niedookreśloność wyrażeń w przepisach prawnych na przykładzie języka polskiego i węgierskiego, Comparative Legilinguistics 13 (2013), s. 49-66, tu: s. 55, por. Vagueness in Normative Texts, red. V.K. Bhatia i in., Linguistic Insights, Vol. 23, (2005), s. 15, 439.

26 T. Brańka, Treść i zakres pojęcia autonomia. Wyzwania definicyjne, Acta Politica Polonica 45 (2018) 3, s. 5-17, cyt. za: J. Iwanek, Współczesne rozumienie autonomii terytorialnej, [w:] Społeczeństwo wobec problemów transformacji i integracji, red. J. Liszka, Ustroń 2000, s. 171-178. 
np. autonomia terytorialna, autonomia kulturowa. W przypadku autonomii terytorialnej chodzi o przyznanie specjalnych uprawnień grupie ludności zamieszkującej określony obszar geograficzny, identyfikowanej jako mniejszość narodowa lub etniczna. Zwykle jest to spowodowane jej odmiennością kulturową czy językową od pozostałej ludności kraju. W Siedmiogrodzie, a szczególnie na Seklerszczyznie, Węgrzy stanowili na niektórych obszarach zwartą, jednorodną grupę, stanowiącą większość. Dlatego politycy węgierscy od momentu rozpoczęcia negocjacji po pierwszej wojnie światowej dążyli do utworzenia w Siedmiogrodzie jednej autonomii terytorialnej lub też kilku obszarów autonomicznych, zgodnie ze wskaźnikiem demograficznym. Autonomia terytorialna z założenia daje mieszkającej tam ludności najsilniejszy mandat do tworzenia własnej administracji, odrębnego sądownictwa, ciała ustawodawczego tworzącego prawo dla wyodrębnionego obszaru, czy też do powołania lokalnego rządu. „Minimalny zakres przekazanych kompetencji powinien zapewnić utrzymanie tożsamości grupy, zaś optymalny - zawierać uprawnienia, których wykorzystywanie nie będzie powodowało zagrożenia dla terytorialnej spoistości państwa” ${ }^{27}$. Tak rozumiana autonomia terytorialna jest w swojej idei dość podobna do samorządu, jednak jest formą silniej wspierającą odrębną tożsamość ludności danego obszaru, daje większe niż samorząd możliwości i uprawnienia. Natomiast autonomia kulturowa może, ale nie musi wiązać się z konkretnym obszarem. Może ona oznaczać jakieś szczególne uprawnienia dla osób połączonych wspólną kulturą, religią, pochodzeniem etnicznym mówiących tym samym językiem, którzy mogą mieszkać w skupiskach lub być rozproszeni na terenie całego kraju ${ }^{28}$.

Centralna Rumuńska Rada Narodowa przesłała 9 XI 1918 r. do rządu w Budapeszcie depeszę, w której zwracała się o pokojowe przekazanie władzy we Wschodnich Węgrzech. Oprócz Siedmiogrodu miały to być tereny komitatów Torontál (rum. Torontal), Temes (rum. Timiş, pol. Temesz), Krassó-Szörény (rum. Caraş Severin), Arad, Bihar (rum. Bihor), Szilágy (rum. Sălaj), Szatmár (rum. Satu Mare), Máramaros (rum. Maramureș, pol. Marmarosz), a także zamieszkałe przez ludność rumuńską obszary w komitatach Csanád, Békés és Ugocsa. W związku z tym 13 listopada rząd węgierski wysłał do Arad delegację pod przewodnictwem ministra Oskara Jásziego w celu rozpoczęcia negocjacji. Zaproponował on, by sporne obszary podzielić na wzór kantonów szwajcarskich na mniejsze jednostki administracyjne,

27 Tamże, s. 12, cyt. za: T. Benedikter, The World's Modern Autonomy Systems: Concepts and Experiences of Regional Territorial Autonomy, Bolzano 2009, s. 39.

28 Tamże, s. 12, cyt. za: R. Lapidoth, Autonomy: Flexible Solutions to Ethnic Conflicts, Washington 1997, s. 36. 
zgodnie z układem demograficznym, tj. na obszarach z większością rumuńską ustalić administrację rządu rumuńskiego, a na obszarach z większością węgierską - administrację rządu węgierskiego. Każda ze stron miała gwarantować zachowanie praw mniejszości narodowych pozostających pod ich jurysdykcją. Przywódcy rumuńscy byli skłonni rozmawiać o autonomii Siedmiogrodu tylko w ramach Królestwa Rumunii, a rumuński polityk Iuliu Maniu domagał się całkowitej suwerenności dla ludności rumuńskiej na całym terenie Węgier Wschodnich ${ }^{29}$.

9 XI 1918 r. w Budapeszcie i 13 XI 1918 r. w Kluż-Napoka (węg. Kolozsvár) ukonstytuowała się Narodowa Rada Seklerów (węg. Székely Nemzeti Tanács). Na zgromadzeniu ogólnym w Budapeszcie opowiedziała się ona za utrzymaniem integralności terytorialnej z Węgrami, z zachowaniem podziału na kantony gwarantującego poszanowanie praw narodowości. 28 listopada zwołano zgromadzenie ogólne w Marosvásárhely (rum. Târgu Mureș). Przed zgromadzeniem prasa przedstawiła rzekome plany Rady na utworzenie Niezależnej Republiki Seklerów, jednak na zgromadzeniu zamiast tego powołano Narodową Radę Węgrów w Siedmiogrodzie (Erdélyrészi Magyar Nemzeti Tanácsot), która miała bronić interesów mieszkającej tam ludności węgierskiej. Uczestnicy zgromadzenia opowiedzieli się za utrzymaniem integralności terytorialnej z Węgrami i wezwali do interwencji wojskowej ${ }^{30}$.

W Alba Iulii (węg. Gyulafehérvár) 1 XII 1918 r. 1228 delegatów na lokalne Zgromadzenie Rumunów z Siedmiogrodu, Banatu i Węgier ogłosiło zjednoczenie z Królestwem Rumunii 26 historycznych województw węgierskich znajdujących się w granicach prowincji Kriszana (węg. Körösvidék, rum. Crișana), Banat (węg. Bánság lub Bánát, rum. Banat) i Marmarosz (węg. Máramaros, rum. Maramureş), uzasadniając to zamieszkiwaniem tego obszaru też przez ludność rumuńską. Chociaż teoretycznie decyzja ta odpowiadała zasadzie samostanowienia narodów prezydenta Wilsona, to jednak w praktyce była to jednostronna decyzja społeczności rumuńskiej. Wspólnota Sasów siedmiogrodzkich jeszcze podczas rozmów w Arad nie była przekonana do takiego rozwiązania. W dzienniku Aradi Közlöny zamieszczono nawet opis kokardy, którą przypięli przybywający do Arad delegaci sascy - miała ona kolory z flagi węgierskiej, z kolorami diaspory saskiej na środku, co miało symbolizować ich wolę pozostania w ramach państwa węgierskiego. Ostatecznie jednak

\footnotetext{
29 Erdély története, s. 1711-1714.

30 N. Bárdi, Székelyföld autonómiája a két világháború közti erdélyi magyar rendezési tervekben (1918-1940), [w:] Nemzeti és etnikai konfliktusok a Kárpát-medencében, Székesfehérvár 2014, s. 3-4.
} 
wspólnota saska zaakceptowała decyzję z Alba Iulii ${ }^{31}$. Głos wspólnoty węgierskiej, która opowiadała się za przynależnością do Królestwa Węgier, w ogóle nie został wzięty pod uwagę.

W deklaracji o przyłączeniu Siedmiogrodu do Rumunii zawarto zapewnienie o szerokich prawach dla wszystkich narodowości. Dokument w ostatecznej formie różnił się od dyskutowanego wcześniej projektu, w którym przewidziano autonomię dla Siedmiogrodu, a jej zasady miało określić zgromadzenie lokalne. Projekt zakładał pełną autonomiczność dla mieszkających razem narodów. Każdy z nich miała mieć prawo do edukacji i sądów we własnym języku, z własną administracją obsługiwaną przez osoby ze swojego narodu, a także do reprezentacji w ciałach ustawodawczych i rządzie krajowym w stosunku proporcjonalnym do liczby ludności. Na takie rozwiązanie nie zgodzili się jednak politycy rumuńscy. Ostatecznie pozostawiono więc zapis, że zgromadzenie narodowe z Alba Iulii ustala autonomię tymczasową dla tych obszarów do czasu pierwszego posiedzenia Konstytuanty wybranej w wyborach powszechnych. W ostatecznej formie deklaracja w punkcie III ustalała zasadę „pełnej wolności” (ale już nie „autonomicznej”) dla wszystkich żyjących wspólnie narodów. Podobnie jak w projekcie, każdy naród miał mieć prawo do edukacji, administracji i sądów prowadzonych przez osoby z własnego narodu i we własnym języku oraz każdy naród, proporcjonalnie do swojej liczebności, miał otrzymać prawo do reprezentacji w organach prawodawczych oraz rządzie krajowym ${ }^{32}$. Jednak, jak pokazała późniejsza praktyka, bez ustalenia faktycznej autonomii założenia te stały się tylko martwym zapisem.

\section{Próby zachowania autonomiczności w ramach państwa rumuń- skiego}

W 1919 r. Rumunia w umowie międzynarodowej zobowiązała się przestrzegać praw mniejszości. Gwarantowała ona narodowościom nierumuńskim równość praw, wolność stosowania języka, własną edukację i możliwość wniesienia skargi do Ligi Narodów, a Seklerom i Sasom autonomię kulturową. Równość wszystkich narodowości wobec prawa potwierdzała konstytucja z 1923 r., z tym, że równocześnie zawierała

31 M. Diaconescu. A „teljes nemzeti szabadság” az 1918. december 1-i gyulafehérvári határozatban, Történelmi szemle LXI (2019), 4. szám, s. 745-762, tu: s. 749.

32 Tamże, s. 753-755. 
ona zapis, że Rumunia to „kraj narodu rumuńskiego”. ${ }^{33}$ Umowy międzynarodowe, zapisy konstytucji, a w szczególności rumuńska praktyka polityczna często były sprzeczne ze sobą, co utrudniało działania na rzecz węgierskiej czy saskiej diaspory. Węgrzy natomiast nie zaprzestali walki o uzyskanie autonomii dla Siedmiogrodu w 1933 r. taki postulat został wpisany do programu rumuńskiej Partii Węgierskiej.

W latach pięćdziesiątych władze socjalistyczne demonstrowały demokratyczność struktur państwowych, a problemy etniczne próbowały wykorzystać politycznie. W 1952 r. utworzona została Autonomiczna Prowincja Węgierska (węg. Magyar Autonóm Tartomány) ze stolicą w Târgu Mureș (węg. Marosvásárhely) - postanowienie to zawarto w konstytucji rumuńskiej, w punktach 19-21. W granicach Autonomii Węgrzy stanowili 77\%, jednak było to zaledwie 30\% ludności węgierskiej zamieszkałej na obszarze Rumunii. Do 1956 r. przygotowano różne projekty statutu Autonomii. Jeden z nich, przygotowany w 1956 r. przez Zoltána Fábiána, jako wzór rozwiązań przyjął Deklarację z Alba Iulii oraz autonomię Abchazów w Gruzji. Ostatecznie jednak, żadne wewnętrzne prawa Autonomii nie zostały oficjalnie wprowadzone. 29 I 1953 r. w prasie lokalnej w Kluż-Napoka ukazał się raport pierwszego sekretarza rumuńskiej partii komunistycznej, według którego problemy mniejszości narodowych w Rumunii zostały rozwiązane. A skoro, jak twierdzily władze, problem przestał istnieć, to nie było już możliwości prowadzenia dalszych negocjacji w celu faktycznego polepszenia losu diaspory węgierskiej. Władze rumuńskie starały się, by w Autonomii nie było obszarów, na których ludność węgierska stanowiłaby ponad 80-90\%, dlatego wyłączyły z niej obszary Aranyosszék (rum. Scaunul Arieșului) i Barcaság (rum. Țara Bârsei), stanowiące homogeniczne tereny seklerskie, pozostawiając tam tylko komitaty Udvarhely (rum. Comitatul Odorheiu), Csík (rum. Comitatul Ciuc), i Maros (rum. Județul Mureș). Przy kolejnych przekształceniach przeprowadzonych w 1960 r. rozdzielono wiele okręgów typowo węgierskich i dołączono do nich obszary zamieszkałe przez ludność rumuńską, zmieniając w ten sposób proporcje etniczne w okręgach administracyjnych. W Autonomii obowiązywało prawo krajowe, a lokalne Zgromadzenie Narodowe mogło tworzyć własne zarządzenia, które musiały być jednak zaakceptowane przez rumuński Parlament. Autonomia była więc faktycznie kierowana centralnie przez organy rumuńskie. Sytuacja stała się nieco łatwiejsza jedynie w kwestii prawa do używania języka węgierskiego w administracji publicznej, ponieważ większość urzędników była Węgrami. Później, kiedy pierwszym sekretarzem partii w Autonomii został Rumun Josif Banc, sytuacja po- 
gorszyła się, ponieważ w urzędach zatrudniono wielu Rumunów. W 1968 r. wprowadzono w Rumunii nowy podział terytorialny - zlikwidowano prowincje i zastąpiono je województwami. W ten sposób zniesiona też została Autonomiczna Prowincja Węgierska, a jej obszary przydzielono do województwa Kovászna (rum. Județul Covasna), Hargita (rum. Județul Harghita) i Maros (rum. Județul Mureș), przy czym przy nowym podziale w ogóle nie uwzględniano już kryteriów etnicznych ${ }^{34}$.

Po zmianie systemu, w latach 1989-2003 sformułowano co najmniej 10 projektów, mających uregulować status diaspory węgierskiej w Rumunii. Do roku 2003 zajmowała się tym powstała w grudniu 1989 r. partia polityczna Demokratyczny Związek Węgrów w Rumunii (węg. Romániai Magyar Demokrata Szövetség RMDSZ), później środowisk było więcej, ponieważ w Rumunii tworzyły się nowe węgierskie ugrupowania polityczne. Sprawa ta stała się też przedmiotem szerszej dyskusji wobec planów włączenia Rumunii w struktury Unii Europejskiej. Początkowe postulaty RMDSZ nie mówiły o autonomii, później zaczęto rozważać również tego typu projekty ${ }^{35}$. 17 I 2004 r. na zgromadzeniu w Sfântu Gheorghe (węg. Sepsiszentgyörgy) Narodowa Rada Seklerów przyjęła projekt statutu o autonomii regionalnej Seklerszczyzny. Rada przekazała ten projekt do dalszego procedowania w parlamencie rumuńskim. Negocjacje prowadzili posłowie RMDSZ. Odbyło się wiele debat, m.in. o to, czy chodzić tu powinno o autonomię regionu - a więc autonomię terytorialną i czy ma ona dotyczyć całej ludności Seklerszczyzny, czy też tylko wspólnoty węgiersko-seklerskiej. Przedyskutowano możliwość procedowania projektu w kontekście obowiązującej konstytucji i prawa rumuńskiego, do tekstu wprowadzono wiele poprawek, dotyczących zarówno kwestii formalnych, jak i językowych. 25 II 2004 r. projekt przesłano do odpowiedniej komisji parlamentarnej, a następnie był on procedowany w kolejnych gremiach Parlamentu i rządu, jednak ostatecznie został on odrzucony ${ }^{36}$.

\footnotetext{
34 G. Fábián, A nemzeti kisebbségi jogok biztosításának alakulása Romániában 1918-2018, avagy, „A gyulafehérvári ígéretek megtagadásától a Minority SafePack ellenzéséig - 100 év romániai kisebbségjogi történet”, Acta Universitatis Sapientiae, Legal Studies 7 (2018) 2, s. 165-261, tu: s. 187-189.

35 M. Bakk, Az autonómia-tervek két szakasza Erdélyben 1989 után. Magyar kisebbség: nemzetpolitikai szemle (2004), 9 évf. 31-32 (1-2.), s. 39-60.

36 T.T. Toró, A Székelyföld autonómia-statútuma tervezetének módosulása a Parlamenthez való benyújtás elött, tamże, czyli gdzie?, s. 295-303.
} 


\section{Zakończenie}

W ciągu niemal tysiąca lat przynależności Siedmiogrodu do Królestwa Węgier miejsce to bądź rozkwitało pod względem gospodarczym i kulturowym, wyróżniając się wśród innych obszarów Europy ze względu na powszechną tam otwartość i tolerancję, bądź było niszczone, a niekiedy wręcz całkowicie pustoszone na skutek wojen z wrogiem zewnętrznym i wewnętrznym. Silnie rozwinięte nacjonalizmy charakterystyczne dla końca XIX i pierwszej połowy XX w. - zarówno węgierskie, objawiające się w dążeniu do madziaryzacji ludności zamieszkałej na obszarze Królestwa Węgier, jak i rumuńskie, bazujące na poczuciu krzywdy związanej z wielowiekowym wykluczeniem - nie pozwoliły na pełne wykorzystanie potencjału, jaki stanowi tysiącletnia tradycja wielokulturowego i wielojęzykowego Siedmiogrodu. Okres po $1920 \mathrm{r}$. z pewnością należy do bardzo trudnych, zarówno pod względem gospodarczym, jak i społeczno-kulturowym. Decyzje z Trianon szczególnie mocno odcisnęły swoje piętno na życiu diaspory węgierskiej, która po przesunięciu granic musiała zacząć funkcjonować w ramach państwa rumuńskiego, mimo że niektóre obszary były zamieszkałe niemal wyłącznie przez ludność węgierską. Niedoceniana wcześniej ludność rumuńska z impetem rozpoczęła proces rozbijania i osłabiania bronionej przez Węgrów autonomii kulturowej. Poczucie krzywdy zakorzenione w obu nacjach zaowocowało trwającymi do chwili obecnej napięciami na tle narodowościowym. Jednym z bardziej dramatycznych przykładów eskalacji emocji były wydarzenia, które miały miejsce 19 i 20 III 1990 r. w stolicy Siedmiogrodu - mieście Târgu Mureș (węg. Marosvásárhely). Doszło wtedy do zamieszek, w których śmierć poniosło trzech Rumunów i trzech Węgrów, a 190 Rumunów i 88 Węgrów zostało rannych. Również w ostatnich latach dochodzi do dyskusji, które zamiast łagodzić napięcia przyczyniają się do atmosfery wzajemnej nieufności. Najbardziej kuriozalne wydaje się budowanie konfliktu na tym, co faktycznie łączy. Za takie działanie uznać można symboliczne spory związane z osobą króla węgierskiego pochodzenia wołoskiego - Macieja Korwina. Niedawno jeden z polityków węgierskich powrócił do teorii o możliwym kumańsko-tatarskim pochodzeniu rodziny Hunyadich. Argumentował on, że w okresie, w którym rodzina ta została włączona do węgierskiej elity na Wołoszczyźnie, szlachectwo otrzymywali kniaziowie kumańscy i tatarscy, a nie „rumuńscy pasterze górscy”. W celu udowodnienia tej tezy zostaną nawet przeprowadzone badania genetyczne kości Jánosa Korwina, syna króla Macieja 
Korwina $^{37}$. Znamienne jest też nieustające zamieszanie wokół pomnika króla Macieja, stojącego na głównym placu miasta Kluż-Napoka. Okazały pomnik z brązu odsłonięto w 1902 r., później stał się on dla Węgrów ważnym symbolem niedawnej przynależności Siedmiogrodu do Królestwa Węgier, a każda ingerencja rumuńska na pomniku, jak choćby umieszczenie na nim napisu w języku rumuńskim czy też (raczej nieprzypadkowe) akty wandalizmu wywołują głębokie oburzenie społeczności węgierskiej. 1 VIII 1990 r. parlament rumuński uchwalił nowe święto narodowe tzw. Wielkie Zjednoczenie Rumunii, obchodzone 1 grudnia, w rocznicę ogłoszenia w 1918 r. Deklaracji z Alba Iulii. Chociaż jego uchwalenie odebrano jako prowokację wobec Węgier, to z czasem wśród ludności Siedmiogrodu utarło się, że 1 grudnia to bardziej święto rumuńskie, a 15 marca świętują Węgrzy. Nie można jednak zaprzeczyć, że obchody 1 grudnia również obecnie mogą stać się zarzewiem konfliktu. Rumuni ze swojej strony naciskają na to, by zamieszkali w ich kraju Węgrzy obchodzili to święto, natomiast politycy z Węgier, w zależności od aktualnych trendów i celów, bądź jadą, bądź nie jadą na obchody tego święta do Rumunii, demonstrując w ten sposób poglądy na przeszły i obecny status Siedmiogrodu.

W ciągu minionych stu lat Węgrzy mieszkający na terenie Rumunii włożyli wiele wysiłku w utrzymanie własnej kultury i języka, wypracowując równocześnie model w miarę stabilnego, choć nie wolnego od problemów współistnienia z narodowością rumuńską. Państwo węgierskie oraz węgierskie organizacje pożytku publicznego starają się wspierać tę diasporę w dążeniach do umocnienia jej tożsamości kulturowej. Rumuńska opinia publiczna niekiedy odbiera te działania negatywnie jako zagrożenie, Węgrów rumuńskich oskarża się o brak lojalności wobec własnego państwa, a działaczy z Węgier - o wtrącanie się w wewnętrzne sprawy rumuńskie. Wydaje się, że wśród rumuńskich mieszkańców Siedmiogrodu ciągle tli się obawa, że Węgrzy szykują się do oderwania tych ziem od Rumunii, chociaż po zmianie systemu w latach dziewięćdziesiątych XX w. Węgry wielokrotnie podkreślały, że nie dążą do rewizji granic - mówi o tym m.in. Traktat między Rumunią a Węgrami o porozumieniu, współpracy i dobrym sąsiedztwie z 16 IX 1996 r. Jednakże w dalszym ciągu niektórzy członkowie węgierskiej diaspory w Rumunii czy też radykalni politycy węgierscy mówią o konieczności utworzenia na obszarze Siedmiogrodu jakiegoś rodzaju autonomii - bądź to kulturowej, bądź terytorialnej ${ }^{38}$. Przynależność Węgier

37 I. Riba, Román lehetett Hunyadi János, de Kásler miniszternek ez nem tetszik. HVG. 2 VIII 2021. https://hvg.hu/360/202105_hunyadilegendak_merlegen_kihantolt_mult_kivanatos_szarmazas csontbrigad [dostęp: 27 II 2021].

38 https://www.maszol.ro/index.php/belfold/105068-a-gyulafehervari-igerete- 
i Rumunii do Unii Europejskiej nie wyklucza walki o prawa węgierskiej diaspory, a wręcz przeciwnie, otwiera nowe możliwości. Przykładem tego jest złożona do Komisji Europejskiej inicjatywa Narodowej Rady Seklerów, pt. „Polityka spójności w regionie na rzecz równości i zachowania kultury regionu"39. Wskazuje się w niej na potrzebę poświęcenia szczególnej uwagi regionom, które ze względu na cechy narodowe, etniczne, kulturowe, religijne lub językowe różnią się od regionów otaczających. Inicjatywę, po wieloletnim sporze, ostatecznie zarejestrowano 7 V 2019 r. i rozpoczęto zbieranie podpisów. Wśród partnerów wspierających projekt, oprócz organizacji węgierskich i przedstawicieli diaspory z Rumunii czy Słowacji, znalazły się m.in. organizacje z Katalonii, a w skład komitetu weszli przedstawiciele Basków, Szwedów, Holendrów czy Belgów. Współpraca z organizacjami wspierającymi podobne cele sprawia, że głos Węgrów siedmiogrodzkich w sprawie autonomii może wybrzmieć na arenie międzynarodowej głośniej niż we wcześniejszych latach.

\section{Bibliografia}

Bakk M., Az autonómia-tervek két szakasza Erdélyben 1989 után. Magyar kisebbség: nemzetpolitikai szemle (2004), 9 évf. 31-32 (1-2.).

Bánkiné Molnár E., Eltünt autonómiák. A Jászkun kerület és Kövár-vidék, [w]: Ingenia et studia. Tanulmányok a 80 esztendös Iványosi-Szabó Tibor tiszteletére, Kecskemét 2013.

Bárdi N., Székelyföld autonómiája a két világháború közti erdélyi magyar rendezési tervekben (1918-1940), [w:] Nemzeti és etnikai konfliktusok a Kárpát-medencében, Székesfehérvár 2014.

Benedikter T., The World's Modern Autonomy Systems: Concepts and Experiences of Regional Territorial Autonomy, Bolzano 2009.

Benkö L., Bóna I., Jakó Zs., Tonk S., Vekov K., Erdély a keresztény magyar királyságban. Erdélyi Tudományos Füzetek 231. Kolozsvár 2011.

Brańka T., Treść i zakres pojęcia autonomia. Wyzwania definicyjne, Acta Politica Polonica 45 (2018) 3.

Czuczor G., Fogarasi J., A magyar nyelv szótára, Pest, [később] Budapest 1862-1874.

ket-kerte-szamon-az-rmdsz-szonoka-a-parlament-centenariumi-ulesen, 2018 [dostęp: 27 II 2021].

39 https://europa.eu/citizens-initiative/initiatives/details/2019/000007_pl [dostęp: 1 III $2021]$. 
Diaconescu M., A „teljes nemzeti szabadság” az 1918. december 1-i gyulafehérvári határozatban, Történelmi szemle LXI (2019), 4. szám.

Erdély rövid története, red. B. Köpeczi, Budapest 1989.

Fábián G., A nemzeti kisebbségi jogok biztositásának alakulása Romániában 1918-2018, avagy, „A gyulafehérvári ígéretek megtagadásától a Minority SafePack ellenzéséig - 100 év romániai kisebbségjogi történet", Acta Universitatis Sapientiae, Legal Studies, 7 (2018) 2.

Fejér Gy., Codex diplomaticus Hungariae ecclesiasticus ac civilis, t. IV, vol. III, 133-136, 1. Budae.

Fodor J.N., Megjegyzések népnévi eredető tulajdonneveinkröl, Névtani Értesítő 34 (2012).

http://lexikon.katolikus.hu/V/Verancsics.html.

https://europa.eu/citizens-initiative/initiatives/details/2019/000007_pl.

https://library.hungaricana.hu/hu/view/KozMagyOkmanytarak_Codex_Diplomaticus_Tom_4_vol_3/?pg=132\&layout=s.

https://mek.oszk.hu/19200/19267/.

https: / / net.jogtar.hu/getpdf docid $=87600033$.TV\&targetdate $=\&$ print Title $=1876$. +évi+XXXIII.+törvénycikk\&refrefe $=1000 \mathrm{ev}$.

https://www.maszol.ro/index.php/belfold/105068-a-gyulafehervari-igereteket-kerte-szamon-az-rmdsz-szonoka-a-parlament-centenariumi-ulesen.

Iwanek J., Wspótczesne rozumienie autonomii terytorialnej, [w:] Społeczeństwo wobec problemów transformacji i integracji, red. J. Liszka, Ustroń 2000.

Kaczmarek K., Precyzja i niedookreśloność wyrażeń w przepisach prawnych na przykładzie języka polskiego i węgierskiego, Comparative Legilinguistics 13 (2013).

Kocsis K., Területi autonómiák a Kárpát-medencében - 1920 előtt. A Miskolci Egyetem Közleményei, A sorozat, Bányászat, 82 kötet (2011).

Köpeczi B., Erdély története három kötetben, Budapest 1986.

Kőváry L., Erdély történelme. 3. kötet (A Zápolyák kora), Pest, Kolozsvár 1860.

Lapidoth R., Autonomy: Flexible Solutions to Ethnic Conflicts, Washington 1997.

Rácz A., Nyugati népek megnevezéseinek változásai a magyar nyelvben, Magyar $\mathrm{Ny-}$ elvjárások 47 (2009).

Riba I., Román lehetett Hunyadi János, de Kásler miniszternek ez nem tetszik. HVG. 2 VIII 2021 https://hvg.hu/360/202105_hunyadilegendak_merlegen_kihantolt_mult_kivanatos_szarmazas_csontbrigad.

Stownik języka polskiego, red. M. Szymczak, t. 1-3, Warszawa 1978-1981.

Szabó M.A., Betekintés az erdélyi szászok autonómiájába, [w: ] Történelmi autonómiák 
a Kárpát-medencében, Székelyudvarhely, G.H. Hermann, Zs. Kolumbán, Csíkszereda 2004.

Tamás L., Az erdélyi oláhság, [w:] A történeti Erdély, red. M. Asztalos, Budapest 2001. Vagueness in Normative Texts, ed. by V.K. Bhatia et al., Linguistic Insights, Vol. 23, (2005).

\section{Summary \\ Territorial and cultural autonomies in Transylvania. The pursuit and interpretations}

For centuries, Transylvania was home to populations speaking different languages and representing numerous cultures, thus creating specific cultural or territorial autonomies where Hungarians, the Székelys, Saxons and Romanians played a special role. In different times, the specific nationalities enjoyed more or fewer privileges. This was either related to their social role or the latest political developments. While for hundreds of years, Vlachs (Romanians) were the least privileged group, in the $20^{\text {th }}$ century Transylvania was incorporated into the Romanian state which dramatically changed the ethnic and social mosaic in the region. Since that time, developing own culture and language by the Hungarian community was increasingly difficult and led to nationality-related tensions. 1918 marked the beginning of discussions about creating some sort of autonomy, cultural or territorial, for the Hungarian population within the Romanian state.

Nadesłany: 1 III 2021

Nadesłany po poprawkach: 29 IV 2021

Zaakceptowany: 4 V 2021

Dr hab. Karolina Kaczmarek, prof. UAM

Uniwersytet im. Adama Mickiewicza w Poznaniu

Wydział Neofilologii

al. Niepodległości 4

61-874 Poznań

e-mail: karkacz@amu.edu.pl 